\title{
A potential record of a procolophonid parareptile from the Triassic of the Iberian Peninsula
}

\author{
J. FORTUNY A. BOLET A.G. SELLÉS À. GALOBART
}

Institut Català de Paleontologia Miquel Crusafont

08201, Sabadell, Barcelona, Spain. Fax: 935868333. Fortuny E-mail: josep.fortuny@icp.cat Bolet E-mail: arnau.bolet@icp.cat García-Sellés E-mail: albert.garcia@icp.cat Galobart E-mail: angel.galobart@icp.cat

A B S T R A C T

Cranial and postcranial remains from the Middle Triassic of the NorthEastern part of the Iberian Peninsula are reported and tentatively assigned to Procolophonidae. The finding is the first occurrence of a procolophonid parareptile in the Iberian Peninsula, representing the southernmost record of the group in Europe. The fossilbearing locality is dated as Anisian (Middle Triassic) and includes three tooth-bearing bones, two cranial bone fragments and one interclavicle. The mandible described herein includes nine teeth. No cusps or complete crowns are preserved, but sections of the teeth are available. The three anterior teeth progressively decrease in size from front to back, while the teeth from the fourth to the eighth position present the opposite trend. The last tooth (the ninth) is clearly reduced in comparison to the previous ones. A close relationship with Anomoiodon-Kapes is suggested, however, more material is required in order to assess the exact taxonomical determination of the Iberian remains. This finding is expected to shed some light on the geographical distribution of procolophonines.

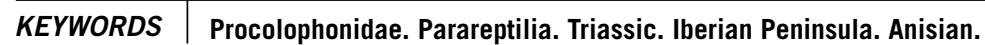

\section{INTRODUCTION}

Procolophonoids were small to middle-sized members of the Parareptilia clade, which survived the end-Permian mass extinction and diversified until the end of the Triassic. In Europe, the oldest occurrences of this group come from the Olenekian of Germany (Säilä, 2008). In addition, a minimum of three different taxa have been reported from the Late Olenekian of Poland, (Borsuk-Białynicka and Lubka, 2009) and Sclerosaurus armatus is known from the Olenekian/ Anisian of Switzerland (Sues and Reisz, 2008). In the Middle Triassic, several procolophonid species are known from the Anisian of England (Spencer and Storrs, 2002). Ruta et al. (2011) pointed out that the Anisian diversity of parareptiles (including procolophonids) is difficult to interpret and attempted to investigate faunal changes via phylogeny-based measures of diversity, and provided minimum estimates of additional, albeit as yet unrecovered diversity. On this aim, any new procolophonid material from unsampled areas has the potential to provide new information to evaluate the parareptile diversity during the Anisian.

Recent sampling efforts in the Triassic of the Iberian Peninsula are revealing a greater taxonomic diversity than previously recognized in the Middle Triassic continental ecosystems, especially for the Anisian (see Fortuny et al., 2011a). New Anisian remains from Catalonia (Spain), consisting in cranial and postcranial material, represent the first potential record of a parareptile from the Iberian Peninsula and from southernmost Europe.

Institutional Abbreviations: IPS, Institut de Paleontologia de Sabadell, collections housed at the Institut Català de Paleontologia Miquel Crusafont (Sabadell, Spain). 


\section{AGE AND GEOLOGICAL SETTING}

The Triassic strata of the Iberian Peninsula are usually divided according to the Germanic facies system. However, these facies are not coeval with those from Central and Western Europe (López-Gómez et al., 2002). The remains described in the present work were found in the Middle Buntsandstein facies (sandstones and mudstones of the Figaró unit) of the Catalonian Basin (Fig. 1), dated as Anisian (Solé de Porta et al., 1987; DinarèsTurell et al., 2005). These fossils were found in 2009 by Albert G. Sellés, Arnau Bolet and Josep Fortuny nearing the farmhouse "Corral d'en Parera". This locality is $1.5 \mathrm{~km}$ away (in straight line) from La Mora site, the type locality of the temnospondyl amphibian Calmasuchus acri (Fortuny et al., 2011b). Previous works already cited the presence of vertebrate ichnites near this locality (Calzada, 1987; Fortuny et al., 2011a).

\section{SYSTEMATIC PALEONTOLOGY}

Parareptilia Olson, 1947.

Procolophonidae Lydekker in Nicholson and Lydekker, 1889. Gen. et sp. indet.

Material. IPS-60866 (Figs. 2, 3), sandstone block containing three tooth-bearing bones (premaxilla, ?maxilla and mandible), two cranial bone fragments (?vomer and maxilla) and an interclavicle.

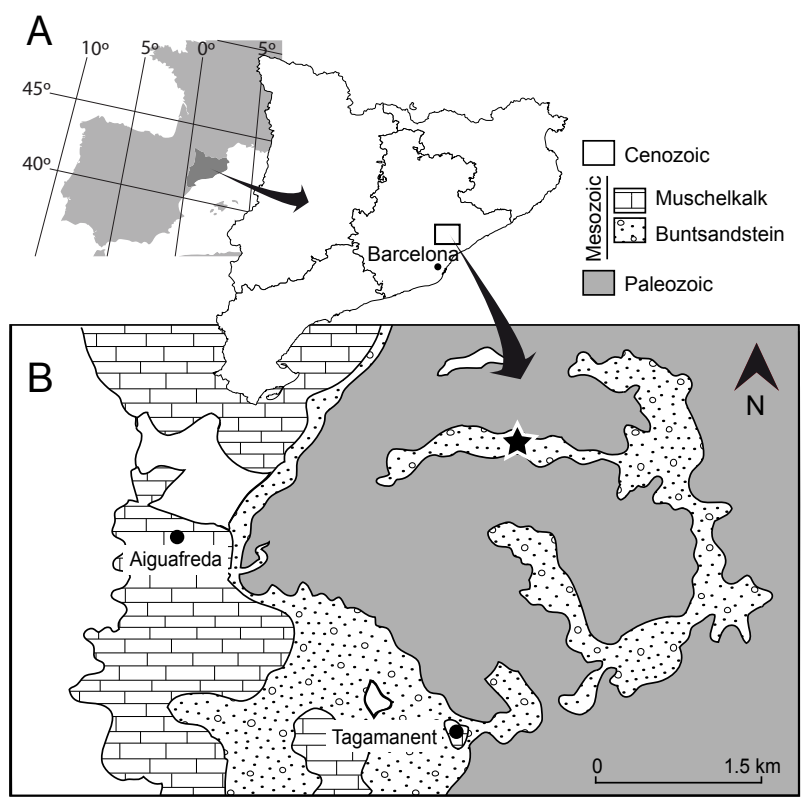

FIGURE 1. Geographical and geological location of the Corral d'en Parera locality. A) Map of Europe with the Catalan region and placement of the vertebrate locality in Barcelona Province. B) Geological map of the Montseny area.

\section{PRESERVATION AND PREPARATION}

The material is embedded in a block of hard matrix constituted of fine sandstone. The teeth are damaged and their cusps are all broken. The block was prepared using chemical and mechanical treatments (see Val et al., 2009 for further methodological details). Some areas were kept embedded in the matrix due to the fragility of the bone in contrast with the hard matrix. After preparation, the material was photographed using a Leica H MZ16A stereomicroscope.

\section{DESCRIPTION}

\section{Cranial remains}

Twelve teeth are present in the block. Unfortunately, no cusps or complete crowns are preserved, but the sections resulting from their breakage provide information regarding their size and shape (Fig. 2). Nine of the exposed teeth are situated close to each other, linearly arranged. We interpret that they probably correspond to the right mandible exposed in occlusal view. The tooth row is slightly sigmoidal, being convex in its anterior half part and concave in the posterior one. The length of the tooth row (from the first to the ninth tooth) is $2.21 \mathrm{~cm}$. The three anterior teeth are oval-shaped in crosssection, where the long axis is oriented anteroposteriorly, especially in the most anterior one. On the other hand, the fourth and the fifth teeth are subcircular in shape, while the sixth to the eighth are more rectangular. The maximum diameter (the longitudinal axis) of the three anterior teeth decreases anteroposteriorly. The fourth tooth is higher than the third one, and the fifth and sixth teeth are slightly larger than the previous ones. The sixth, seventh and eighth teeth all have a similar size. Despite its poor preservation, it is possible to observe that the posteriormost tooth (the ninth) is clearly reduced in size compared to the others.

Regarding the inter-tooth distance, it is variable depending on the position (see Appendix I for the exact measures). It is remarkable that the distance between the third and fourth teeth is the greatest, although it does not correspond to a real diastema.

An isolated tooth is present close to the interpreted labial side of the mandible, at the level of the fifth tooth position. The cross-section of this tooth is subcircular, with a maximum diameter of $3.4 \mathrm{~mm}$, representing the largest preserved tooth in the block.

Two additional teeth are placed close to the anterior part of the supposed right mandible. This region may correspond to the premaxilla or, less probably, the anterior part of the right maxilla. If true, the visible part of these 

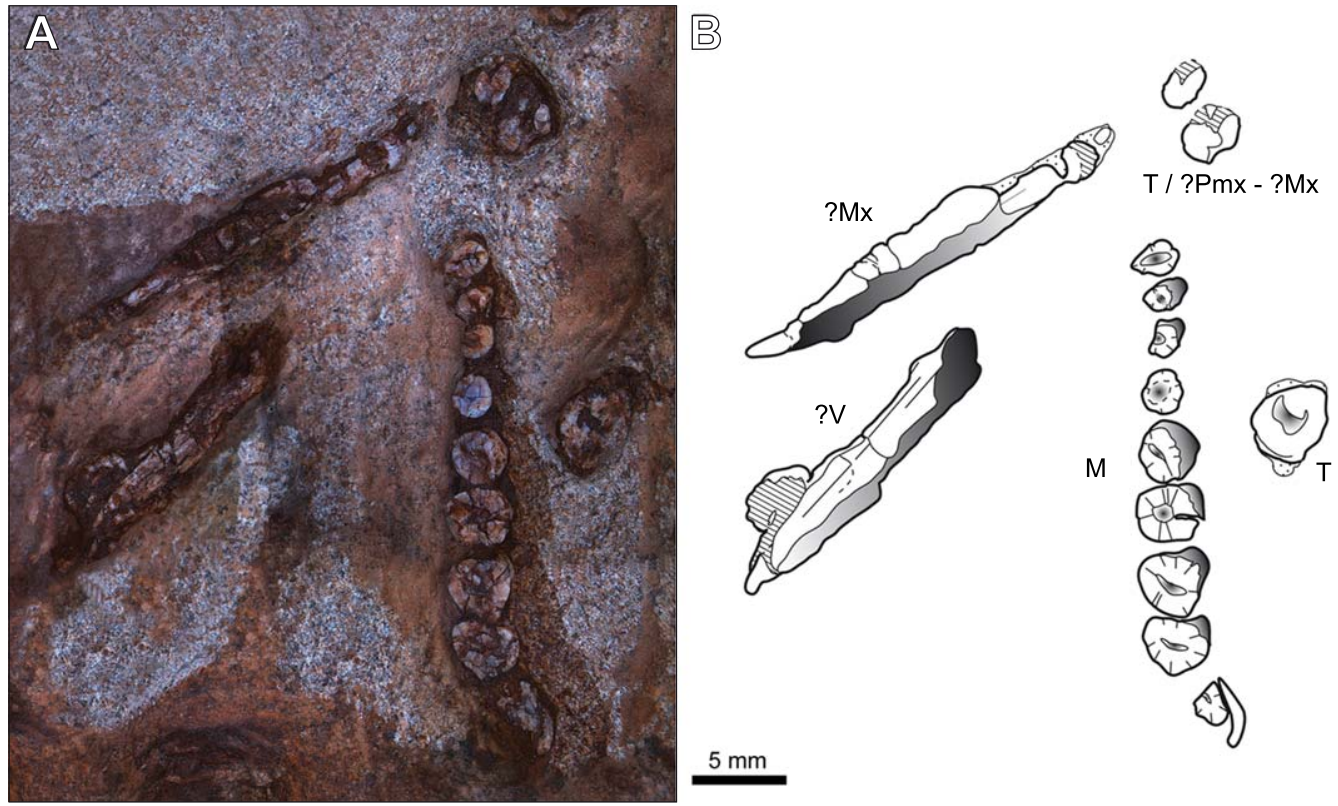

FIGURE 2. Teeth and cranial bone fragments of the procolophonid specimen (IPS-60866) from the Corral d'en Parera locality (Catalonian Basin, Anisian). A) Photograph. B) Drawing. M: mandible. Mx: Maxilla. Pmx: Premaxilla. T: Tooth. V: Vomer.

teeth would correspond to their base, with a cusp possibly preserved (and embedded) inside the matrix. These two teeth are close to a large bone structure that was probably displaced. This bone structure measures $1.6 \mathrm{~cm}$, with a maximum thickness of $1.7 \mathrm{~mm}$. If this structure represents the premaxilla-maxilla, the corresponding teeth might still be embedded in the matrix. Another bone structure lies on the right of (but does not appear to connect with) the possible maxilla. Based on its position, this bone may correspond to the posterior part of the vomerine plate. No evidence of denticles has been found in this structure.

\section{Postcranial remains}

The greatest part of an interclavicle is exposed revealing a T-shaped outline (Fig. 3). The left lateral process of the interclavicle is missing but the right one is almost complete, just missing its tip. The lateral processes of the interclavicle are concave (ventral view). The distal part of the lateral process is U-shaped, although it could be related to an artifact of preservation. Both lateral ends are connected by a tranverse ridge that runs along the anterior border of the bone. The anterior margin of the transverse ridge is roughly straight. A second ridge runs along the median process posteriorly. Both ridges are nearly perpendicular and meet anteriorly, forming a subtriangular area.

\section{DISCUSSION}

A T-shaped interclavicle with slender lateral projections has been used to characterize the Permian pareiasaurs and the Triassic procolophonid parareptiles (Laurin and Reisz, 1995). The concave morphology of the lateral processes of the interclavicle in ventral view is clearly different from the straight shape found in Leptopleuroninae and similar to that found in the genus Procolophon. Otherwise, the mandible of the procolophonoids contains several diagnostic characters (Cisneros, 2008). In this group, the dentary holds a variable number of teeth that shows a clear trend towards a decrease through time. The teeth of the interpreted mandible differ from the typical leptopleuronine shape (sensu Cisneros, 2008). The members of this clade only bear one incisiveform tooth on the dentary (Sues et al., 2000; Cisneros and Schultz, 2003) whereas IPS-60866 has, at least, three (with an oval section) (Fig. 2). Moreover, the presence of six to seven teeth on the dentary, a synapomorphy Leptopleuroninae (Cisneros, 2008), is not accomplished by IPS-60866. Additionally, the teeth of the Catalan specimen increase in size posteriorly, differing from the typical tooth shape found in the Leptopleuroninae dentary. The specimen IPS-60866 shows a similar tooth count (eight-nine teeth) as the Gondwanan Procolophon trigoniceps, Thelerpeton oppressus, Thelephon contritus and Teratophon spinigenis, the North American Acadiella psalidodon, the northern Chinese Eumetabolodon bathycephalus, the European Sclerosaurus armatus and Procolina teresae as well as the Russian genera Timanophon and Tichvinskia. On the one hand, it should be noted that the length of the tooth row of IPS-60866 is $2.24 \mathrm{~cm}$, which is significantly longer than in some of the genera mentioned above, such as Procolophon (1.4-1.8cm), Acadiella psalidodon $(1.5 \mathrm{~cm})$, Procolina $(0.7-1.15 \mathrm{~cm})$, Tichvinskia $(1.4 \mathrm{~cm})$ or Timanophon $(1.1 \mathrm{~cm})$ (Novikov, 1991; Sues and Baird, 

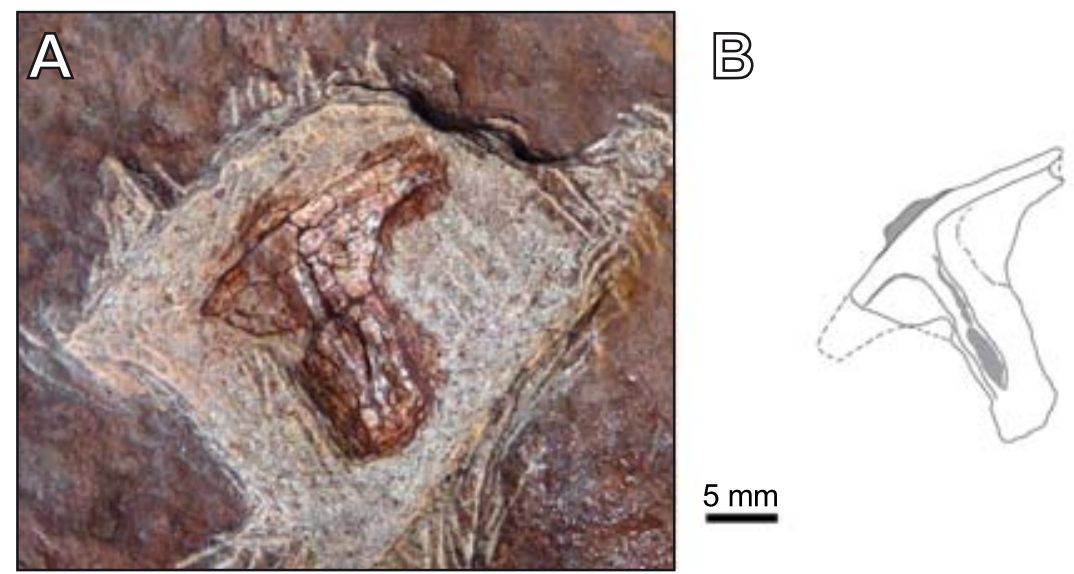

FIGURE 3. Interclavicle of the procolophonid specimen (IPS-60866) from the Corral d'en Parera locality (Catalonian Basin, Anisian). A) Photograph. B) Drawing.

1998; Spencer and Benton, 2003; Borsuk-Białynicka and Lubka, 2009). Otherwise, Procolophon, Eumetabolodon bathycephalus and Timanophon display molariform teeth with transversely expanded bases (Carroll and Lindsay, 1985; Li, 1983; Novikov, 1991), which is not the case of the specimen herein described. Regarding Eumetabolodon bathycephalus, several specimens have been described. The largest $E$. bathycephalus are comparable in size with the Catalan specimen; however, as previously mentioned, the former taxon differs from the latter in the presence of a transverse expansion of the posterior teeth (Li, 1983). The poorly-known Acadiella differs from IPS-60866 in presenting two incisiform teeth instead of three. However, both share conical-subcircular post-incisiform teeth that increase in size from front to back, lacking transverse expansions. Acadiella shares with the specimen described herein a last tooth that is significantly smaller than the four anteriorly situated ones, but differs from it in having the antepenultimate tooth broader than long (Sues and Baird, 1998). The Anisian Thelerpeton oppressus from South Africa possesses teeth that are bulbous at their base, and differs from the specimen IPS-60866 in its transversely wide molars. Another Anisian taxon from South Africa, T. spinigenis, shares a similar number of teeth with the specimen IPS-60866 although no dental description is available yet, precluding comparisons (Gow, 1977; Modesto and Damiani, 2003).

The European Sclerosaurus displays conical teeth on the dentary, while IPS-60866 shows an heterodont dentition with sections that clearly vary between the most anterior (oval-shaped) and the posterior ones (molariformlike), with only the fourth and the fifth teeth being similar in section to those of the former (Sues and Reisz, 2008). The genus Procolina has an enlarged tooth in the mandible, as well as other taxa. In Procolina, it usually corresponds to the fifth or the sixth tooth (Borsuk-Białynicka and Lubka,
2009). In IPS-60866 there is no evidence of a dominant tooth (Fig. 3), although the lack of cusps precludes confirmation of this character. Regarding the Cisuralian Russian genera, the affinities with Timanophon have been discussed above, while Tichvinskia is significantly smaller than IPS-60866. The tooth sections of the specimen here described, the presence of three anterior teeth with similar morphology, and the presence of a posterior molariform tooth, are all characters reminiscent of the genus Tichvinskia. Moreover, this genus presents a small posterior tooth (Spencer and Benton, 2003), also found in IPS-60866. Considering other Cisuralian Russian procolophonids, Kapes requires a special attention. This genus, known from Russia and England (Ivakhnenko, 1979; Spencer and Storrs, 2002; Novikov and Sues, 2004), was erected from remains that appeared to be larger than those of Tichvinskia. They also presented differences in the number and shape of teeth as well as in the presence of a large tooth in the mandible (Spencer and Benton, 2003). Kapes usually has six to seven dentary teeth, in contrast to the nine observed in IPS60866. Moreover, Kapes shares with the Catalan specimen its dental pattern: three anterior teeth that decrease in size from front to back, followed by posterior teeth with a subcircular-rectangular molariform morphology that increase in size from front to back, and lacking transverse expansions. In Kapes, the interdistance between teeth resembles that of IPS-60866. Kapes is characterized by the usual presence of a very large tooth (the penultimate) on the mandible, with the presence of a small tooth in the posteriormost position. As previously mentioned, a small posterior tooth was found in IPS-60866, while no dominant tooth is present.

Another Anisian taxon, Thelephon contritus from South Africa, also shares a similar number of teeth with the described specimen, and the presence of a posterior dominant molar tooth with Kapes. However, the validity 
of the genus Telephon is controversial due to the lack of autapomorphic characters (Modesto and Damiani, 2003) and a revision of this taxon is in progress (Cisneros, 2008). Turning back to Kapes, this genus was suggested to be synonym of Anomoiodon from the Olenekian of Germany (Spencer and Storrs, 2002). In Anomoiodon the teeth increase in size from front to back, differing from Kapes and IPS-60866, where the three anterior teeth progressively decrease in size posteriorly.

Because other groups of diapsid reptiles are known from the Triassic period, and owing to the preservation state of the remains herein described, the assignment to any other group cannot be completely discarded. However, some Triassic tetrapod groups are far to be well known (see Sues and Schoch, 2013 for an example). It is difficult to discard the possibility that our remains belong to these poorly known taxa, but we consider that an adscription to Procolophonidae, based on the presence of a T-shaped interclavicles, as well as the dental morphology, is better justified.

Taking the issues discussed above into account, the peculiar preservation of the Catalan specimen precludes a detailed comparison that would clarify if it corresponds to any previously-known procolophonid or to a new taxon. We suggest that IPS-60866 might represent a taxon closely related to Anomoidon-Kapes. It should also be noted that an affinity with Tichvinskia cannot be discarded, although to date this genus is only known from the Early Triassic. The number of teeth (nine) in the interpreted mandible of IPS-60866 would be an unusual tooth-count in Kapes, Anomoiodon or Tichvinskia, although differences by one or two additional teeth have been previously reported for other taxa (Li, 1983; Borsuk-Białynicka and Lubka, 2009).

A replacement of procolophonines by leptopleuronines occurred during the Anisian (Borsuk-Białynicka and Lubka, 2009). The first procolophonines known from Europe are Early Triassic in age (Anomoiodon, Procolina), and genera like Kapes presented a wide, at least Eurasian, distribution during the Anisian (Ivakhenko, 1979; Spencer and Storrs, 2002; Novikov and Sues, 2004). For procolophonids, and specially procolophonines, the paleobiogeographic radiation is neither simple nor unequivocal; different dispersal scenarios are equally probable as proposed by Cisneros and Ruta (2010). The possible presence of a taxon possibly related to Anomoiodon or Kapes in the Iberian Peninsula would expand the geographical distribution of these forms. The record herein reported is the southernmost European finding of a potential procolophonid and its assignment to procolophonines let us to hypothesize two different scenarios: on the one hand, related forms (Anomoiodon-Kapes group) originated in Russia and migrated achieving a wide distribution in Europe as suggested by the findings in Central Europe (Säilä, 2008), England (Spencer and Storrs, 2002) and Iberian Peninsula (this work). The lack of procolophonid evidences in North Africa hampers discussion on whether these forms also conquered the northern part of the African plate or if they were restricted to the European plate. On the other hand, the presence of the genus Thelephon in South Africa opens a second scenario, since this taxon has been found to nest with the genus Kapes. Cisneros (2008) suggested that this genus might be a synonym of the former. If true, a second scenario is possible, with Kapes representing a transPangean genus, and IPS-60866 as a potential additional record from southernmost Europe. Nevertheless, more material is necessary to clarify the taxonomy and relationships of the Iberian procolophonid, although the large geographical gap between South-African and Central European-Russian procolophonids is partially filled by the new record here reported.

\section{CONCLUSIONS}

A specimen preserving the interclavicle, three toothbearing bones (?premaxilla, ?maxilla and mandible) and two cranial bone fragments (?vomer and maxilla) is herein described and tentatively assigned to the Procolophonidae. The finding of procolophonid remains in the Anisian of the Catalonian Basin represents the first evidence of parareptiles in the Iberian Peninsula and their southernmost European record. The assignment is provisional, because more material would be required to formally refer the material to either a previously known taxon or to a new one. Nevertheless, the Anisian remains here described suggest the presence of a taxon that might be related to Anomoiodon-Kapes or to the basal Early Triassic Tichvinskia, based on the length of the tooth row, teeth count, the dental distribution pattern and that the molariform-like teeth lacks transverse expansions. The presence of procolophonids in the Iberian Peninsula partially fills the large gap between the Central EuropeanRussian faunas and the South African ones and reveals that procolophonids completely conquered Europe through one of at least two different paleobiogeographic scenarios open to debate. The Iberian finding is of special interest to elucidate the geographical distribution pattern of forms related to Anomoiodon-Kapes.

\section{ACKNOWLEDGMENTS}

We thank I. Novikov (PIN, Moscow), L. Costeur (NMB, Basel), and J. Müller (MfN, Berlin) for access to material under their care. Thanks to Judit Marigó and Silvia Pineda for helpful comments. This research was supported by a Synthesys grant (DE-TAF-5309) to JF. Economic support was provided by the 
Departament de Cultura de la Generalitat de Catalunya. The revisions of Juan Carlos Cisneros, Marcello Ruta and Sean P. Modesto greatly improved a previous version of this manuscript.

\section{REFERENCES}

Borsuk-Białynicka, M., Lubka, M., 2009. Procolophonids from the Early Triassic of Poland. Palaeontologia Polonica, 65, 107-144.

Calzada, S., 1987. Niveles fosilíferos de la facies Buntsandstein (Trias) en el sector norte de los Catalánides. Cuadernos Geología Ibérica, 11, 256-271.

Carroll, R.L., Lindsay, W., 1985. Cranial anatomy of the primitive reptile Procolophon. Canadian Journal of Earth Sciences, 22, 1571-1587.

Cisneros, J.C., 2008. Phylogenetic relationships of procolophonid parareptiles with remarks on their geological record. Journal of Systematic Palaeontology, 6, 345-366.

Cisneros, J.C., Schultz, C.L., 2003. Soturnia caliodon n. g. n. sp., a procolophonid reptile from the Upper Triassic of Southern Brazil. Neues Jahrbuch für Geologie und Paläontologie, Abhandlungen, 227(3), 365-380.

Cisneros, J.C., Ruta, M., 2010. Morphological diversity and biogeography of procolophonids (Amniota: Parareptilia). Journal of Systematic Palaeontology, 8(4), 607-625.

Dinarès-Turell, J., Díez, B.J., Rey, D., Arnal, I., 2005. "Buntsandstein" magnetostratigraphy and biostratigraphic reappraisal from eastern Iberia: Early and Middle Triassic stage boundary definitions through correlation to Tethyan sections. Palaeogeography, Palaeoclimatology, Palaeoecology, 229, 158-177.

Gow, C.E., 1977. New procolophonids from the Triassic Cynognathus Zone of South Africa. Annals of the South African Museum, 72(6), 109-124.

Fortuny, J., Bolet, A., Sellés, A.G., Cartanyà, J., Galobart, À., 2011a. New insights on the Permian and Triassic vertebrates from the Iberian Peninsula with emphasis on the Pyrenean and Catalonian basins. Journal of Iberian Geology, 37(1), 65-86.

Fortuny, J., Galobart, À., De Santisteban, C., 2011b. A new capitosaur from the Middle Triassic of Spain and the relationships within the Capitosauria. Acta Palaeontologica Polonica, 56(3), 553-566.

Ivakhnenko, M.F., 1979. Permskiye I triasovyye prokolofony Russkoy platform (in Russian). Trudy Paleontologicheskogo Instituta Akademiya Nauk (SSSR), 164, 1-80.

Laurin, M., Reisz, R.R., 1995. A reevaluation of early amniote phylogeny. Zoological Journal of the Linnean Society, 113, 165-223.
$\mathrm{Li}, \mathrm{J} ., 1983$. Tooth replacement in a new genus of procolophonid from the early Triassic of China. Palaeontology, 26, 567-583.

López-Gómez, J., Arche, A., Pérez-López, A., 2002. Permian and Triassic. In: Gibbons, W., Moreno, T. (eds.). The Geology of Spain. Geological Society Publishing House, 185-212.

Modesto, S.P., Damiani, R.J., 2003. Taxonomic status of Thelegnathus browni Broom, a procolophonid reptile from the South African Triassic. Annals of the Carnegie Museum, 72, 53-64.

Novikov, I.V., 1991. New data on the procolophonids of the USSR. Paleontologicheskiy Zhurnal, 1991(2), 73-85.

Novikov, I.V., Sues, H.-D., 2004. Cranial osteology of Kapes (Parareptilia: Procolophonidae) from the Lower Triassic of Orenburg Province, Russia. Neues Jahrbuch für Geologie und Paläontologie, Abhandlungen, 232, 267-281.

Ruta, M., Cisneros, J.C., Liebrecht, T., Tsuji, L., Müller, J., 2011. Amniotes through major biological crises: faunal turnover among parareptiles and the end-Permian mass extinction. Palaeontology, 54(5), 1117-1137.

Säilä, L.K., 2008. The osteology and affinities of Anomoiodon liliensterni, a procolophonid reptile from the Lower Triassic Buntsandstein of Germany. Journal of Vertebrate Paleontology, 28(4), 1199-1205.

Solé de Porta, N., Calvet, F., Torrentó, L., 1987. Analisis palinológico del Triásico de los Catalánides (NE España). Cuadernos de Geología Ibérica, 11, 237-254.

Spencer, P.S., Storrs, G.W., 2002. A re-evaluation of small tetrapods from the Middle Triassic Otter Sandstone formation of Devon, England. Palaeontology, 45(3), 447-467.

Spencer, P.S., Benton, M.J., 2003. Procolophonoids from the Permo-Triassic of Russia. In: Benton, M.J., Shishkin, M., Unwin, D.M. (eds.). The age of dinosaurs in Russia and Mongolia. Cambridge, Cambridge University Press, 160-177.

Sues, H.D., Baird, D., 1998. Procolophonidae (Reptilia:Parareptilia) from the Upper Triassic Wolfville Formation of Nova Scotia, Canada. Journal of Vertebrate Paleontology, 18(3), 525-532.

Sues, H.D., Reisz, R.R., 2008. Anatomy and phylogenetic relationships of Sclerosaurus armatus (Amniota: Parareptilia) from the Buntsandstein (Triassic) of Europe. Journal of Vertebrate Paleontology, 28(4), 1031-1042.

Sues, H.D., Schoch, R.R., 2013. First record of Colognathus (? Amniota) from the Middle Triassic of Europe. Journal of Vertebrate Paleontology, 33(4), 998-1002.

Sues, H.D., Olsen, P.E., Scott, D.M., Spencer, P.S., 2000. Cranial osteology of Hypsognathus fenneri, a latest Triassic procolophonid reptile from the Newark Supergroup of Eastern North America. Journal of Vertebrate Paleontology, 20(2), 275-284.

Val, S., Fortuny, J., García-Alix, A., García-Martínez, R., 2009. MATRIX: Technological world against the hard sediments. Paleontologia i Evolució, 4 (Memòria especial), 265-273.

Manuscript received September 2012; revision accepted March 2014; published Online May 2014. 


\section{ELECTRONIC APPENDIX I}

TABLE I. Measurements (in $\mathrm{mm}$ ) of the right mandible found in specimen IPS-60866

\begin{tabular}{lrrrrrrrrr}
\hline Tooth & 1 & 2 & 3 & 4 & 5 & 6 & 7 & 8 & 9 \\
$\begin{array}{l}\text { Maximum } \\
\text { diameter }\end{array}$ & 2.1 & 1.9 & 1.6 & 1.94 & 2.4 & 3.0 & 3.0 & 3.0 & 2.1 \\
$\begin{array}{l}\text { Interdistance } \\
\text { 0.5 }\end{array}$ & 0.5 & 0.8 & 0.5 & 0.2 & 0.7 & - & - & \\
\hline
\end{tabular}

